\title{
STRATEGI PENINGKATAN KUALITAS SUMBER DAYA APARATUR SIPIL NEGARA (ASN) KABUPATEN SUMEDANG PROVINSI JAWA BARAT (Studi di BKPSDM Kabupaten Sumedang)
}

\author{
Oleh \\ Sonia Sugian", \\ Sampara Lukman ${ }^{2}$, Ella L. Wargadinata ${ }^{3}$ \\ ${ }^{1)}$ Dewan Perwakilan Rakyat Daerah (DPRD) Kabupaten Sumedang \\ Program Magister Terapan Studi Pemerintahan Daerah Institut Pemerintahan Dalam Negeri \\ sonia_sugian@yahoo.com \\ ${ }^{2,3)}$ Institut Pemerintahan Dalam Negeri
}

\begin{abstract}
STRATEGY FOR IMPROVING THE QUALITY OF APPARATUS RESOURCES (ASN) SUMEDANG REGENCY WEST JAVA PROVINCE (STUDY AT BKPSDM SUMEDANG REGENCY)
\end{abstract}

The Law of the Republic of Indonesia Number 5 of 2014 concerning the State Civil Apparatus 1 (ASN) mandates that the implementation of personel management is carried out on the basis of a merit system. The era of bureaucratic reform in good governance or good governance requires qualified and professional apparatus. Based on this understanding, local governments must be able to build a well-organized personel management system, especially in the process of developing civil servants. The aim is to identify and analyze strategies for improving the quality of apparatus resources.

The research method used by the author is descriptive qualitative research method with an inductive approach. Data collection techniques were carried out by interview, observation and documentation as well as using triangulation data analysis techniques for determining strategies with SWOT analysis.

In general, the improvement of the quality of apparatus resources in the BKPSDM of Sumedang Regency is good. However, currently there are still obstacles so that it is still not optimal. The implementation of the education and training is still not in accordance with the needs of the organization, and is still oriented towards a budget approach. For transfer of Civil Servants, refer to Government Regulation No. 13 of 2002 concerning Appointment of Civil Servants in Structural Positions. Benefits of optimizing the planning of apparatus resource management in improving the quality of apparatus performance.

Keywords: strategy, quality, apparatus resources

\section{Abstrak}

$\mathrm{U}$ ndang-Undang No. 5 Tahun 2014 tentang Aparatur Sipil Negara (ASN) mengamanatkan bahwa pelaksanaan manajemen kepegawaian dilaksanakan atas dasar merit system. Era reformasi birokrasi penyelenggaraan pemerintah yang baik atau good governance 
membutuhkan aparatur yang berkualitas dan profesional. Berdasarkan pemahaman tersebut maka pemerintah daerah harus mampu membangun sebuah sistem manajemen kepegawaian yang tertata dengan baik, khususnya dalam proses pengembangan Pegawai Negeri Sipil. Tujuan untuk mengetahui dan menganalisis strategi peningkatan kualitas sumber daya aparatur.

Metode penelitian yang digunakan penulis yaitu metode penelitian kualitatif deskriptif dengan pendekatan induktif. Teknik pengumpulan data dilakukan dengan wawancara, observasi dan dokumentasi serta menggunakan teknik analisis data triangulasi untuk penentuan strategi dengan analisis SWOT.

Pada umumnya peningkatan kualitas sumber daya aparatur di Badan Kepegawaian dan Pengembangan Sumber Daya Manusia (BKPSDM) Kabupaten Sumedang baik. Namun saat ini masih ada kendala sehingga masih belum optimal. Pelaksanaan Diklat masih belum sesuai kebutuhan organisasi, dan masih berorientasi pada pendekatan anggaran. Untuk mutasi Pegawai Negeri Sipil merujuk pada Peraturan Pemerintah No. 13 Tahun 2002 tentang Pengangkatan Pegawai Negeri Sipil Dalam Jabatan Struktural. Manfaat optimalisasi perencanaan penataan sumber daya aparatur dalam peningkatan kualitas kinerja aparatur.

Kata kunci: strategi, kualitas, sumber daya aparatur

\section{PENDAHULUAN}

$\mathrm{R}^{\mathrm{e}}$ eformasi Birokrasi merupakan upaya untuk melakukan pembaharuan, pembenahan dan perubahan yang mendasar terhadap sistem penyelenggaraan pemerintahan terutama dalam aspek-aspek kelembagaan, tata laksana, dan sumber daya aparatur negara. Berbagai hambatan yang mengakibatkan sistem penyelenggaraan pemerintahan belum berjalan dengan baik diperlukan penataan ulang dan pembaharuan dalam rangka mewujudkan tata kelola pemerintahan yang baik (good governance). Dengan kata lain reformasi birokrasi adalah langkah strategis untuk membangun aparatur negara agar lebih berdaya guna dan berhasil guna dalam mengemban tugas umum pemerintahan dan pembangunan nasional.

Konsekuensi tersebut dimaksudkan guna melakukan perbaikan, pembaharuan dan perubahan dasar terhadap penyelenggaraan pemerintahan sesuai dengan Peraturan Presiden No. 81 Tahun 2010 tentang Grand Design Reformasi Birokrasi yang menyebutkan delapan area perubahan reformasi birokrasi yang mencakup; 1) organisasi; 2) tata laksana; 3) peraturan perundang-undangan; 4) sumber daya manusia pegawai; 5) pengawasan; 6) akuntabilitas; 7) pelayanan publik; dan 8) pola pikir (mind set) dan budaya kerja (culture set) pegawai

Proses peningkatan kinerja pegawai pemerintah dapat dicapai, manakala sumber daya manusia (aparat) memiliki kompetensi dan motivasi yang tinggi dalam berkerja. Di dalam organisasi pemerintahan, sumber daya manusia tercermin pada Pegawai Negeri Sipil sebagai aktor pelaksana pemerintahan. Kelancaran penyelenggaraan pemerintahan dan peningkatan kinerja Pegawai sangat tergantung pada kualitas pegawai karena itu dalam rangka mencapai tujuan pembangunan nasional, yakni mewujudkan masyarakat madani yang taat hukum, demokratis, adil, makmur dan bermoral tinggi, diperlukan pegawai sebagai unsur pegawai negara dan abdi masyarakat yang mampu menjalankan tugasnya dengan sebaik-baiknya, yang dilandasi oleh kesetiaan, disiplin, loyalitas, memiliki kemampuan yang memadai, profesional dan bertanggung jawab, tunduk dan patuh terhadap peraturan perundangundangan yang berlaku serta kesetiaan dan ketaatan kepada Pancasila dan UndangUndang Dasar 1945. 
Masih rendahnya Penyelenggaraan pemerintahan daerah di Kabupaten Sumedang dikarenakan sumber daya manusia belum efektif, efisien, transparansi dan akuntabel.menanggapi hal tersebut salah satu program percepatan untuk mendukung reformasi birokrasi, yang menjadi perhatian pemerintah adalah Profesionalisasi Sumber Daya Aparatur (PNS). sebagai tuntutan masyarakat di era global dalam pelayanan prima yang diberikan oleh pemerintah semakin meningkat karena secara umum dari aspek kehidupan segala bidang mengalami pertumbuhan.

Kualitas sumber daya manusia merupakan kunci utama dalam menjalankan otonomi yang luas bagi daerah. Hal ini didasarkan pada asumsi bahwa kewenangan yang diserahkan kepada pemerintah daerah hanya dapat ditangani dengan baik manakala didukung oleh sumber daya manusia yang berkualitas. Kinerja organisasi pemerintah dapat dicapai, jika sumber daya aparatur memiliki kemampuan dan kompetensi dalam berkerja. Dalam organisasi pemerintahan, sumber daya manusia tercermin pada Pegawai Negeri Sipil (PNS) sebagai aparat (aktor) pelaksanaan pemerintahan.

Sejalan dengan hal tersebut di atas maka sebagai landasan teori dalam penelitian ini menurut Koswara (2015: 287) yang menyatakan bahwa: Kemampuan profesional dan keterampilan teknis para pegawai yang termasuk kepada unsur staf dan pelaksana di lingkungan pemerintah daerah ini sangat diperlukan agar manajemen pemerintahan dalam otonomi daerah dapat berlangsung secara efektif dan efisien. yang diperlukan tidak hanya jumlahnya yang cukup, tetapi juga kualitas para pegawai yang harus diukur dengan melihat latar belakang pendidikan, keterampilan, pengalaman kerja, jenjang kepangkatan dan status kepegawaian. dengan demikian pengukuran sesuai hal tersebut di atas meliputi tingkat pendidikan, pengalaman, pengetahuan dan keterampilan, yang diperlukan oleh setiap aparatur guna melaksanakan tugas dan fungsinya dalam rangka pencapaian tujuan organisasi.

Undang-Undang No. 5 Tahun 2014 tentang Aparatur Sipil Negara merupakan salah satu peraturan yang menjadi titik tolak perubahan wajah birokrasi Indonesia sehingga dapat mendukung pemerintah dalam mendukung reformasi birokrasi. Undang-undang ini diharapkan akan memaksa dan menjadikan birokrasi untuk merubah kondisi yang selama ini dikeluhkan oleh masyarakat seperti birokrasi yang dianggap lamban dalam memberikan pelayanan, penyelewengan internal di lingkungan pemerintahan yang dilakukan pegawai negeri sipil, masih kurangnya pengetahuan, keterampilan dan disiplin kerja. Masih terdapat pejabat struktural yang belum mengikuti Diklat Kepemimpinan; Pelaksanaan Diklat masih dilaksanakan di masing-masing instansi/OPD sehingga tidak ada koordinasi dengan pihak Badan Kepegawaian dan Pengembangan Sumber Daya Manusia Kab.Sumedang, Kurangnya kemampuan, tingkat pengetahuan dan keterampilan aparatur, dalam menjalankan Tugas dan fungsi Sikap dan perilaku aparat dalam penyelenggaraan layanan yang cenderung mengabaikan kebutuhan dan harapan pihak yang dilayani, karena kurangnya disiplin dalam melaksanakan tugas. Kurangnya pengawasan dan perhatian pimpinan terhadap aparatur sipil negara dalam rangka mewujudkan tujuan organisasi.

\section{Rumusan Masalah}

Rumusan masalah yang penulis sajikan dalam strategi peningkatan kualitas sumber daya aparatur yaitu sebagai berikut.

1. Bagaimana Peningkatan Kualitas Sumber Daya Aparatur ASN Kabupaten Sumedang?

2. Faktor-faktor apa saja yang mendukung dan menghambat Peningkatan Kualitas Sumber Daya Aparatur ASN Kabupaten Sumedang? 
3. Bagaimana Strategi Badan Kepegawaian Pendidikan dan Latihan dalam Proses Peningkatan Sumber Daya Aparatur ASN Kabupaten Sumedang Provinsi Jawa Barat?

\section{TINJAUAN PUSTAKA}

\section{Konsep Strategi}

Strategi secara luas dapat dipandang sebagai pola tujuan, kebijakan, program, tindakan, keputusan atau alokasi sumber daya, Sukses tidaknya strategi yang disusun, perlu diketahui konsep dari strategi tersebut. Rangkuti (2014: 4-5) menjelaskan bahwa: Konsep-konsep strategi tersebut adalah sebagai berikut: a. Distinctive Competence: tindakan yang dilakukan oleh perusahaan agar dapat melakukan kegiatan lebih baik dibandingkan dengan pesaingnya; $b$. Competitive Advantage: kegiatan spesifik yang dikembangkan oleh perusahaan agar lebih unggul dibandingkan dengan pesaingnya.

Kemudian, Sedarmayanti (2014: 22) menyatakan bahwa dalam proses perumusan memerlukan pendekatan sistematis, yang terdiri dari:

1. Menetapkan misi.

2. Menyusun sasaran.

3. Melakukan pengamatan lingkungan internal dan eksternal untuk memperkirakan kekuatan dan kelemahan internal serta peluang dan ancaman eksternal

4. Melakukan analisis strategi yang ada untuk menetapkan hubungannya dengan penilaian internal dan eksternal.

5. Tetapkan kapabilitas khusus organisasi.

6. Menetapkan masalah Strategis utama yang timbul dari analisis sebelumnya.

7. Menetapkan strategi korporasi dan fungsional untuk mencapai sasaran dan keunggulan kompetitif, mempertimbangkan masalah strategis utama.
8. Menerapkan strategi.

9. Memantau penerapan dan menyempurnakan strategi yang telah ada atau mengembangkan strategi baru bila diperlukan.

Selanjutnya Mintzberg dan Water dalam Henee dan Desmidt (2010: 56) menyatakan bahwa, berbagai penyebab kesulitan untuk menerapkan rumusan strategi yang dikehendaki ke dalam pelaksanaan nyata secara utuh, terletak pada dua fakta, yakni: Pertama, hampir selalu terjadi strategi yang telah dirumuskan dalam kenyataannya tidak mungkin dapat direalisasikan dikarenakan ada kendala untuk pengimplementasiannya; dan Kedua, formulasi strategi yang rasional hanya sebagian saja yang berhasil diimplementasikan dikarenakan ada titipan (pendomplengan) strategi lain yang muncul belakangan yang bersifat oportunis dan terlampau dipaksakan (inkonsisten).

Menurut Wechsler dan Backoff dalam Henee dan Desmidt (2010: 62), penerapan strategi organisasi publik pada akhirnya dipengaruhi oleh lima faktor eksternal dan tujuh faktor internal. Faktor internal, yaitu: a. Kepemimpinan. b. Kapasitas dari organisasi. c. Kesepakatan internal mengenai. wewenang yang berlaku. d. Ruang kebebasan yang tersedia melalui pelimpahan pengendalian dari atasan. e. Bonafiditas dari sumber-sumber keuangan alternative. f. Perkembangan dalam teknologi jasa. Adapun faktor eksternal, yaitu: a. Sarana yang tersedia. b Persyaratan yang diminta para stakeholder. c. Pengaruh dari agenda politik. d. Dukungan publik terhadap organisasi dan aktivitasnya. e. Perimbangan kekuatan politik. f. Badan hukum dalam organisasi.

Kegiatan perencanaan merupakan bagian dari manajemen strategis yang di dalamnya mencakup perencanaan (planning), pelaksanaan (implementing) dan pengawasan (controlling). dan pengertian ini perencanaan strategis merupakan suatu bagian dari keseluruhan kegiatan 
manajemen. Hal ini sejalan dengan pendapat Suradinata (2008: 118-119) bahwa:

Manajemen strategis meliputi gambaran kondisi lingkungan yang terjadi (environmental scanning) baik eksternal maupun internal, perumusan strategis (strategis implementation) dan evaluasi serta control (evaluation and control) untuk mencapai tujuan yang sudah ditetapkan sejak awal. Dengan demikian, manajemen strategis memberikan penekanan pada monitoring dan evaluasi kesempatan (opportunity) dan ancaman (threat) yang berasal dari luar (eksternal) dalam kerangka kekuatan (strength) dan kelemahan (weakness) institusi itu sendiri (internal).

Guna mendapatkan rumusan strategi suatu kebijakan yang akan dijalankan maka terlebih dahulu harus melalui tahap penetapan dan mengidentifikasi isu-isu strategis, yakni pernyataan dasar yang akan dijawab dengan memperhatikan faktor-faktor yang memengaruhi strategi tersebut. Lebih lanjut faktor-faktor yang memengaruhi strategi itu, menurut Bryson dalam Miftahuddin (2008: 98) dapat dikelompokkan sebagai berikut.

1. Faktor lingkungan eksternal, yaitu semua kondisi, kecendrungan dan pengaruh dari luar institusi yang menentukan keberhasilan pengembangan misi dan pencapaian visi institusi. Semua faktor ini harus diperhitungkan karena dapat menjadi ancaman bagi institusi atau sebaliknya menjadi peluang. kepada peluang yang dimunculkan oleh perubahan tersebut.

2. Faktor lingkungan Internal, yakni semua kondisi yang berasal dari dalam organisasi yang dapat menjadikan kekuatan atau sebaliknya kelemahan. Adapun kondisi tersebut dapat berupa faktor sumber daya yang terdiri dari manusia, ekonomi, informasi dan kemampuan faktor strategi yang disiapkan secara menyeluruh atau secara fungsional/bagian. Dan faktor pelaksanaan yang berupa hasil (output) dan sejarah.

Berpijak dari beberapa pendapat tentang strategi yang telah disampaikan di atas, maka suatu organisasi diharapkan dapat merumuskan suatu konsep manajemen strategi untuk membuat keputusan sekarang dengan mengingat konsekuensi masa depan, menangani keadaan yang berubah dengan cepat secara efektif, serta menciptakan prioritas dan memecahkan masalah utama organisasi.

\section{Konsep Pengembangan Sumber Daya Manusia}

Sumber daya manusia merupakan salah satu dari dua aset utama yang sangat penting dalam menentukan keberhasilan pembangunan suatu bangsa selain sumber daya alam. Notoatmodjo (2009: 2-8) membagi definisi pengembangan sumber daya manusia menjadi dua cara:

1. Pengembangan sumber daya manusia secara makro (2009: 2) adalah suatu proses peningkatan kualitas atau kemampuan manusia dalam rangka mencapai suatu tujuan pembangunan bangsa.

2. Pengembangan sumber daya manusia secara mikro (2009: 8) adalah suatu proses perencanaan pendidikan, pelatihan dan pengelolaan tenaga atau karyawan untuk mencapai suatu hasil optimal. Hasil ini dapat berupa jasa maupun benda atau uang. Dari batasan ini dapat disimpulkan bahwa proses pengembangan sumber daya manusia itu terdiri dari perencanaan (planning), pendidikan dan pelatihan (education and training), dan pengelolaan (management).

Dari uraian-uraian tersebut dapat disimpulkan, bahwa pengembangan sumber daya manusia baik secara mikro maupun 
secara makro pada hakikatnya adalah merupakan upaya untuk merealisasikan semua kebutuhan manusia.

Menurut Kadarisman (2013: 21), memang sebagian para ahli terperangkap dalam istilah yang menyamakan seolah-olah pengembangan identik dengan pelatihan. Padahal pelatihan bukanlah merupakan salah satunya alat untuk pengembangan sumber daya manusia dalam organisasi. Oleh sebab itu, pengembangan (development) sumber daya manusia mempunyai dimensi luas yang bertujuan meningkatkan potensi yang dimiliki sumber daya manusia, sebagai upaya meningkatkan profesionalisme dalam organisasi. Dengan demikian, istilah pengertian latihan dan pendidikan, yaitu sebagai sarana peningkatan keterampilan dan pengetahuan umum bagi karyawan.

Selanjutnya Hasibuan (2008: 71-72), menjelaskan jenis-jenis pengembangan karyawan/pegawai:

1. Pengembangan secara in formal, yaitu karyawan/pegawai atas keinginan dan usaha sendiri melatih dan mengembangkan dirinya dengan mempelajari buku-buku literature yang ada hubungannya dengan pekerjaan atau jabatannya. Pengembangan secara informal menunjukkan bahwa karyawan tersebut berkeinginan keras untuk maju dengan cara meningkatkan kemampuan kerjanya. Hal ini bermanfaat bagi organisasi karena prestasi kerja karyawan semakin pesat, di samping efisiensi dan produktivitasnya juga semakin baik.

2. Pengembangan secara formal, yaitu karyawan/pegawai ditugaskan organisasi untuk mengikuti pendidikan atau latihan, baik yang dilakukan oleh organisasi maupun yang dilaksanakan oleh lembaga-lembaga pendidikan atau latihan. Pengembangan secara formal dilakukan organisasi karena tuntutan saat ini ataupun masa datang, yang sifatnya non-karier atau peningkatan karier seorang karyawan.

Sementara itu, Sedarmayanti (2014: 167) pengembangan ditinjau dari masa pelaksanaannya, pelatihan sebagai bagian dari tugas pengembangan dapat dibedakan menjadi tiga, yaitu:

1. Pre-service training (pelatihan pratugas) adalah pelatihan yang diberikan kepada calon pegawai yang akan memulai bekerja, atau pegawai baru yang bersifat pembekalan, agar mereka dapat melaksanakan tugas yang nantinya dibebankan pada mereka.

2. In service training (pelatihan dalam tugas) adalah pelatihan dalam tugas yang dilakukan untuk pegawai yang sedang bertugas dalam organisasi dengan tujuan meningkatkan kemampuan dalam melaksanakan pekerjaan.

3. Post service training (pelatihan purna/pasca tugas) adalah pelatihan yang dilaksanakan organisasi untuk membantu dan mempersiapkan pegawai menghadapi pensiun, misalnya pelatihan wirausaha, pelatihan peternakan, pertanian, dan lain-lain.

Kemudian Sedarmayanti(2014:168)juga menyatakan bahwa apabila pengembangan sumber daya manusia tidak dilakukan dalam organisasi, akan terlihat beberapa gejala, antara lain; 1) sering berbuat kesalahan dalam bekerja, 2) tidak pernah berhasil memenuhi standar kerja, seperti tuntutan pada uraian pekerjaan, 3) mempunyai pola pikir sempit, 4) tidak mampu menggunakan peralatan yang canggih dalam bekerja, 5) akan tetap tinggal bodoh dan terpaut pada pekerjaan rutin, 6) produktivitas kerja tidak meningkat, 7) kesinambungan organisasi tidak bisa/sulit dipertahankan, 8) rasa kepedulian rendah di kalangan sumber daya manusia terhadap organisasi, 9) organisasi tidak mampu bersaing dengan organisasi yang mengembangkan sumber daya manusia terus menerus, 10) organisasi ketinggalan 
dalam memberikan pelayanan yang baik kepada pelanggan.

\section{Manajemen Kualitas Sumber Daya Manusia}

Manajemen adalah ilmu dan seni yang mengatur proses pemanfaatan sumber daya manusia dan sumber daya lainnya secara efektif dan efisien untuk mencapai suatu tujuan tertentu. Manajemen ini terdiri dari enam unsur (6 M), yaitu: men, money, method, materials, machines, dan market. Unsur men (manusia) ini berkembang menjadi suatu bidang ilmu manajemen yang disebut manajemen sumber daya manusia. Adapun pengertian manajemen sumber daya manusia adalah ilmu dan seni yang mengatur hubungan dan peranan tenaga kerja agar efektif dan efisien membantu terwujudnya tujuan organisasi/perusahaan, karyawan dan masyarakat.

Kualitas SDM dapat diukur dari keberhasilan: (1) peningkatan kemampuan teoretis adalah suatu kapasitas individu untuk mengerjakan berbagai tugas dalam suatu pekerjaan; (2) peningkatan kemampuan teknis adalah metode atau sistem mengerjakan sesuatu pekerjaan; (3) peningkatan kemampuan konseptual adalah mampu memprediksi segala sesuatu yang memprediksi segala sesuatu yang ada kaitannya sasaran yang akan dituju; (4) peningkatan moral adalah mampu melaksanakan koordinasi, mampu bekerja sama, selalu berusaha menghindari perbuatan tercela dan mampu bersedia mengembangkan diri; (5) peningkatan keterampilan teknis.

Peranan sumber daya manusia di dalam perkembangan teknologi industri sangat berperan sekali. Walaupun teknologi secanggih apa pun tidak dapat berjalan jika tidak diproses oleh manusia. Istilah SDM mengandung konotasi yang bersangkutan dengan kondisi manusia pada umumnya, baik di dalam maupun luar organisasi. Dalam praktik, istilah SDM khususnya dalam organisasi sering disebut dengan istilah kepegawaian (personalia), sehingga dalam praktik manajemen SDM lebih sering disebut manajemen personalia.

Menurut Decenzo dan Robbins (1999: 8) dinyatakan bahwa: "Human resources management it is the part of the organization that is concerned with the "people" or human resources aspect of management position, including recruiting, screening, training, rewarding, and appraising". Sebagai pendekatan dalam sebuah organisasi, MSDM menitikberatkan manusia sebagai aset yang paling bernilai di dalam organisasi, tujuannya adalah agar manusia yang ada di dalam suatu organisasi mampu bekerja secara individual ataupun kolektif, dan secara bersamasama memberikan kontribusinya dalam pencapaian tujuan organisasi.

Dalam rangka mengatasi masalahmasalah yang berhubungan dengan kualitas sumber daya aparatur, setiap pemimpin perlu menempatkan tenaga ahli di dalam bidangnya masing-masing. Para ahli tersebut agar dapat dengan cepat mengendalikan pegawai dan sumber daya manusianya, maka dapat diciptakan iklim kerja yang harmonis, aparatur-aparatur ditempatkan sesuai dengan keahlian dan kemampuannya. Mangkunegara (2008: 5) menjelaskan tentang kepentingan perencanaan sumber daya manusia, yaitu:

1. Kepentingan Individu.

Perencanaan sumber daya manusia sangat penting bagi setiap individu pegawai, karena dapat membantu meningkatkan potensinya, begitu pula kepuasan pegawai dapat dicapai melalui perencanaan karier.

2. Kepentingan Organisasi.

Perencanaan sumber daya manusia sangat penting bagi organisasi (perusahaan) dalam mendapatkan calon pegawai yang memenuhi kualifikasi. Dengan adanya perencanaan sumber 
daya manusia, dapat dipersiapkan caloncalon pegawai yang berpotensi untuk menduduki posisi manajer untuk masa yang akan datang

3. Kepentingan Nasional.

Perencanaan sumber daya manusia sangat bermanfaat bagi kepentingan nasional. Hal ini karena pegawaipegawai yang berpotensi tinggi dapat dimanfaatkan pula oleh pemerintah dalam rangka meningkatkan produktivitas nasional. Mereka dapat dijadikan tenaga-tenaga ahli dalam bidang tertentu untuk membantu program pemerintah.

Setiap aparatur akan mampu melakukan suatu tindakan apabila memang ada kekuasaan untuk mengerahkan atau menggerakkan segala dayanya dalam organisasi. Hal itu, tentunya ini berkaitan dengan potensi yang dimiliki oleh personel atau pribadi (aparatur), sebagaimana pendapat Thoha (2008: 316) bahwa "kemampuan merupakan salah satu unsur dalam kematangan berkaitan dengan pengetahuan dan keterampilan yang diperoleh dari pendidikan, latihan dan pengalaman". Dalam konteks kualitas sumber daya aparatur di era otonomi, Koswara (2015: 287) menyatakan bahwa:

Kemampuan profesional dan keterampilan teknis para pegawai yang termasuk kepada unsur staf dan pelaksana di lingkungan pemerintah daerah ini sangat diperlukan agar manajemen pemerintahan dalam otonomi daerah dapat berlangsung secara efektif dan efisien. yang diperlukan tidak hanya jumlahnya yang cukup, tetapi juga kualitas para pegawai yang harus diukur dengan melihat latar belakang pendidikan, keterampilan, pengalaman kerja, jenjang kepangkatan dan status kepegawaian.

Bertolak dari pendapat-pendapat di atas, maka proses pengembangan sumber daya pegawai (aparatur) dalam penelitian ini agar berkualitas meliputi tingkat pendidikan, pengalaman, pengetahuan dan keterampilan, yang diperlukan oleh setiap aparatur guna melaksanakan tugas dan fungsinya dalam rangka pencapaian tujuan organisasi.

\section{Konsep Pemerintahan Daerah}

Undang-Undang No. 23 Tahun 2014 tentang Pemerintahan Daerah yang bertujuan untuk mempercepat terwujudnya kesejahteraan masyarakat melalui peningkatan pelayanan, pemberdayaan, dan peran serta masyarakat, serta peningkatan daya saing daerah dengan memperhatikan prinsip demokrasi, pemerataan, keadilan, dan kekhasan suatu daerah dalam sistem Negara Kesatuan Republik Indonesia. Secara historis, Undang-Undang 23 Tahun 2014 bukanlah Undang-Undang yang pertama mengatur tentang Pemerintahan Daerah dirunut dari awal:

1. Undang-Undang No. 1 Tahun 1945 tentang Kedudukan Komite Nasional Daerah.

2. Undang-Undang No. 22 Tahun 1948 tentang Pokok Pemerintahan Daerah

3. Undang-Undang No. 1 Tahun 1957 tentang Pokok-Pokok Pemerintahan Daerah

4. Undang-Undang No. 18 Tahun 1965 tentang Pokok-Pokok Pemerintahan Daerah

5. Undang-Undang No. 5 Tahun 1974 tentang Pokok-Pokok Pemerintahan di Daerah

6. Undang-Undang No. 22 Tahun 1999 tentang Pemerintahan Daerah

7. Undang-Undang No. 32 Tahun 2004 tentang Pemerintahan Daerah.

8. Dan terakhir Undang-Undang No. 23 Tahun 2014 tentang Pemerintahan Daerah.

Sumaryadi (2010: 20-21) mengemukakan bahwa konsep pemerintah berkaitan dengan: 
1. Badan-badan publik yang bertanggung jawab dalam sebagian atau seluruh rute penyediaan jasa atau layanan melalui otoritas atau privatisasi.

2. Pemerintah dalam arti luas yang meliputi konsep trias politica (eksekutif, legislatif dan yudikatif).

3. Tingkatan pemerintah yang mulai dari pemerintah pusat hingga pemerintah daerah.

Selanjutnya Labolo (2010: 15), mengemukakan bahwa istilah pemerintah menurut Finer dalam Kuper setidaknya menunjuk pada empat pengertian pokok, yaitu:

1. Pemerintah merujuk pada suatu proses pemerintahan di mana kekuasaan dioperasionalisasikan oleh mereka yang memegang kekuasaan secara sah.

2. Istilah pemerintah menunjukkan pada keberadaan di mana proses pemerintahan tersebut berlangsung.

3. Pemerintah menunjukkan secara langsung person (orang) yang menduduki jabatan-jabatan pemerintah sebagai pelaksana kekuasaan.

4. Istilah pemerintah juga mengacu pada aspek bentuk, metode atau sistem pemerintahan dalam suatu masyarakat, yakni struktur dan pengelolaan badan pemerintah serta hubungan yang memerintah dan yang diperintah.

Sedangkan wikipedia.com, daerah dalam konteks pembagian administratif di Indonesia, adalah kesatuan masyarakat hukum yang mempunyai batas-batas wilayah yang berwenang mengatur dan mengurus urusan pemerintahan dan kepentingan masyarakat setempat menurut prakarsa sendiri berdasarkan aspirasi masyarakat. Daerah terdiri atas Provinsi, Kabupaten, atau Kota. Sedangkan kecamatan, desa, dan kelurahan tidaklah dianggap sebagai suatu Daerah Otonom. Daerah dipimpin oleh seorang Kepala Daerah, yaitu:
Gubernur/Bupati/Wali kota, dan memiliki Pemerintahan Daerah serta Dewan Perwakilan Rakyat Daerah.

Kemudian Labolo (2013: 21) juga mengemukakan bahwa: pemerintahan merupakan gejala yang lebih umum dibandingkan terminologi pemerintah itu sendiri. Pemerintahan menunjukkan pada aktivitas kekuasaan dalam berbagai ranah publik. Ia tidak saja merujuk pada aktivitas dalam berbagai konteks kelembagaan dengan tujuan mengarahkan, mengendalikan, mengatur semua hal yang berkaitan dengan ranah publik seperti kepentingan warga Negara, pemilik suara (voters) maupun para pekerja (workers). Jika peran sebatas pada otoritas politik semata guna menjaga ketenteraman dan ketertiban melalui fungsi eksekutifnya, maka menurut Robinson dalam Labolo, pemerintahan lebih mengacu pada proses pengelolaan politik, gaya atau model pengurusan masalah-masalah umum serta pengelolaan daya umum. Dalam konteks itu, menurutnya setidaknya terdapat tiga nilai penting yang menjadi sentrum dalam pembicaraan pemerintahan, yaitu akuntabilitas, legitimasi, dan transparansi.

\section{METODE PENELITIAN}

Penelitian merupakan suatu proses mencari sesuatu secara sistematis dalam kurun waktu tertentu dengan menggunakan metode berdasarkan aturan tertentu, dengan didukung oleh penguasaan teori atas fenomena yang ada di lapangan.

Menurut Effendy (2010: 2), penelitian secara etimologi berasal dari kata "research" (re: kembali, search: mencari), artinya penyelidikan sistematik dan studi tentang material, sumber-sumber teori dan fenomena yang bertujuan untuk membangun fakta dan mencapai sebuah simpulan. Secara lebih luas, Marczyk, DeMatteo dan Festinger (2005: 46) mengatakan bahwa:

Research is an examination of the relationship between one or more 
independent variables and one or more dependent variables. In even more precise terms, we can define research as an examination of the effects of one or more independent variables on one or more dependent variables.

Hillway, dalam Moh. Nazir (2014: 4) mengemukakan bahwa: "penelitian tidak lain dari suatu metode studi yang dilakukan oleh seseorang melalui penyelidikan yang hatihati dan sempurna terhadap suatu masalah, sehingga diperoleh pemecahan yang tepat terhadap masalah tersebut". Selanjutnya Wasistiono (2014: 44) mengemukakan bahwa metodologi diartikan sebagai cara mendekati, mengamati, dan menjelaskan suatu gejala dengan menggunakan landasan teori. Kemudian dari beberapa pengertian penelitian yang telah diungkapkan, maka dapat diambil simpulan bahwa secara khusus tujuan penelitian yaitu:

1. Meningkatkan atau mengembangkan pengetahuan;

2. Menyelidiki masalah tertentu yang memerlukan jawaban;

3. Menangkap opportunity atau peluang;

4. Memverifikasi fenomena yang terjadi dengan suatu teori yang telah ada;

5. Melakukan pengujian terhadap fenomena untuk menggugurkan, memperkuat. Bahkan menemukan suatu teori yang baru.

Metode penelitian yang penulis gunakan adalah metode kualitatif pendekatan deskriptif.

Menurut Sugiyono (2011: 11), penelitian deskriptif adalah: "penelitian yang dilakukan untuk mengetahui nilai variabel mandiri, baik satu variabel atau lebih (independen) tanpa membuat perbandingan, atau menghubungkan antara variabel satu dengan variabel yang lain. Dengan demikian penelitian deskriptif hanya menggambarkan variabel yang akan di teliti tanpa membandingkan antara satu variabel dengan yang lain". Dengan demikian, penelitian merupakan suatu metode untuk menemukan kebenaran, sehingga penelitian juga merupakan metode berpikir secara kritis.

Guna mengetahui peningkatan kualitas sumber daya aparatur ASN Kabupaten Sumedang, dengan metode yang digunakan penulis dalam penelitian ini adalah metode penelitian kualitatif deskriptif dan pendekatan induktif. Menurut Creswell (2009: 4) menyatakan:

Qualitative research is a mean for exploring and understanding the meaning individuals or groups ascribe to a social or human problem. The process or research involves emerging questions and procedures, data typically collected in the participant's setting, data analysis inductively building from particulars to general themes, and the research making interpretations of the meaning of the data. The final written report has a flexible structure. Those who engage in this from of inquiry support a way of looking at research the honors an inductive style, a focus on individual meaning, and the importance of rendering the complexity of a situation.

Menurut Moleong (2014: 6) penelitian kualitatif adalah penelitian yang bermaksud untuk memahami fenomena tentang penelitian yang dialami oleh subjek penelitian misalnya perilaku, persepsi, motivasi, tindakan, dll,. Secara holistik, dan dengan cara deskripsi dalam bentuk katakata dan bahasa pada suatu konteks khusus yang alamiah dan dengan memanfaatkan berbagai metode alamiah.

Teknik pengumpulan data merupakan sebuah proses yang harus dikerjakan sebagai tolak ukur capaian keberhasilan suatu penelitian, karena dalam pengumpulan data penulis harus dapat menentukan semua kegiatan yang menemukan, menentukan, menyusun fakta-fakta atau data yang berada 
di lokasi penelitian.

Arikunto (2013: 172) mendefinisikan sumber data menjadi tiga, yaitu:

\section{Person (sumber data berupa orang)}

Merupakan sumber data yang bisa memberikan data berupa jawaban lisan melalui wawancara atau tanya jawab tertulis untuk memberikan keterangan yang relevan, yaitu: (1) Kepala Badan Kepegawaian dan Pengembangan Sumber Daya Manusia Kabupaten Sumedang (2) Kepala Sekretariat Badan Kepegawaian dan Pengembangan Sumber Daya Manusia (3) Kepala bidang pengembangan pegawai (4) Kepala Sub Bidang Pengembangan Potensi (5) Staf Badan Kepegawaian dan Pengembangan Sumber Daya Manusia bidang pengembangan pegawai.(6) Perwakilan dari masing-masing Dinas Pemerintahan Daerah Kabupaten Sumedang.

\section{Paper (sumber data berupa symbol)}

Yaitu data yang disajikan dengan menggunakan tanda-tanda berupa huruf, angka, gambar, atau simbol-simbol lain. Sumber data lainnya yang penulis gunakan yaitu berupa file, dokumen, maupun arsip yang mendukung fokus penelitian yang dijadikan referensi yaitu Dokumen Rencana Strategis BKPSDM Kabupaten Sumedang Tahun 2014-2018, Laporan Penyelenggara Pemerintah Daerah Kabupaten Sumedang Tahun 2017, dan Profil BKPSDM Kabupaten Sumedang Tahun 2017, RPJMD dan LAKIP BKPSDM Kabupaten Sumedang.

\section{Place (sumber data berupa tempat)}

Meliputi tempat atau lokasi serta situasi dan kondisi tempat penelitian. Sumber data jenis ini meliputi fenomena yang terjadi di lokasi penelitian berkaitan dengan tema dari penelitian. Place yang digunakan adalah Badan Kepegawaian, Pendidikan dan Pelatihan Kabupaten. Sumedang dengan alamat kantor Jalan
Empang No. 1 Sumedang Kode Pos 45311. BKPSDM Kab. Sumedang sebagai instansi pemerintah yang mempunyai tugas mengelola kepegawaian di Kabupaten Sumedang.

Susan Stainback dalam Sugiyono (2015: 244) menjelaskan:

"Data analysis is critical to the qualitative research process. It is to recognition, study, and understanding of interrelationship and concept in your data that hypotheses and assertions can be developed and evaluated". Analisis data merupakan hal yang kritis dalam proses penelitian kualitatif. Analisis digunakan untuk memahami hubungan dan konsep dalam data sehingga hipotesis dapat dikembangkan dan dievaluasi.

Silalahi (2012: 332), menyebutkan bahwa analisis data adalah proses penyederhanaan data dan penyajian data dengan mengelompokkannya dalam satu bentukyang mudah dibaca dan diinterpretasi. Teknik analisis data yang digunakan dalam penelitian ini adalah teknis analisis induktif, yaitu analisis yang berpangkal dari kenyataan-kenyataan khusus sehingga menghasilkan simpulan yang bersifat umum. Jadi, semua pendapat atau informasi dari data yang diperoleh dengan menggunakan wawancara dan kuesioner yang diperkuat dengan hasil dokumentasi diambil simpulan secara umum.

Berdasarkan pendapat para ahli di atas maka penulis menyimpulkan bahwa teknik analisis data merupakan langkah untuk menyederhanakan semua data yang telah dikumpulkan untuk diambil suatu simpulan terkait masalah yang diangkat penulis sehingga bisa lebih dipahami dan dimengerti. Dalam penelitian ini, penulis menggunakan teknik analisis data Triangulasi.

Triangulasi data digunakan sebagai alat bantu dalam meningkatkan peneliti terhadap data dan fakta yang telah dimiliki. Wiliam Wersma dalam Sugiyono (2014: 
273) menyatakan bahwa Triangulation is qualitative croee-validation. It assesses the sufficiency of the data according to the convergence of multiple data sources or multiple data collection procedures. Dengan demikian terdapat triangulasi sumber, triangulasi teknik pengumpulan data, dan waktu.

Teknik triangulasi melakukan check, recheck, dan crosscheck terhadap data yang di peroleh, teori, metodologi dan peneliti. Triangulasi juga merupakan teknik pemeriksaan yang memanfaatkan sesuatu di luar data, yaitu untuk keperluan pengecekan sebagai pembanding data. Triangulasi yang digunakan dalam penelitian ini, triangulasi sumber dan triangulasi teknik pengumpulan data. Triangulasi dengan sumber data adalah membandingkan fenomena lapangan peneliti. Untuk mendapatkan data secara akurat maka peneliti melakukan check, recheck dan crosscheck terhadap beberapa sumber informasi, juga dilakukan triangulasi teknik pengumpulan data. Dalam hal ini di mana dilakukan pengecekan data kepada sumber yang sama dengan teknik yang berbeda. Data yang di peroleh berupa wawancara lalu di cek dengan observasi dan dokumentasi. Jika dari hasil pemeriksaan kredibilitas data tersebut menghasilkan data yang berbeda-beda maka peneliti melakukan diskusi lebih lanjut untuk memastikan data mana yang dianggap benar.

Dari uraian tersebut di atas, dapat garis bawahi bahwa analisis data bermaksud untuk mengorganisasikan data. Data yang terkumpul tentu akan banyak, yang terdiri dari catatan lapangan dan komentar peneliti, gambar, foto, dokumen, berupa laporan, biografi, artikel, dan sebagainya. Pekerjaan analisis data dalam hal ini ialah dalam hal mengatur, mengurutkan, mengelompokkan, memberikan kode, dan mengategorikannya. Pengorganisasian dan pengelolaan data tersebut bertujuan menemukan tema dan hipotesis kerja yang akhirnya diangkat menjadi teori substantif.
Langkah-langkah yang digunakan dalam analisis data adalah:

1. Reduksi Data

Menurut Sugiyono, "Mereduksi data berarti merangkum, memilih hal-hal pokok, memfokuskan pada hal-hal yang penting, dicari tema dan polanya, dan membuang yang tidak perlu." Melihat dari pengertian tersebut, dapat dipahami bahwa data yang telah direduksi akan memberikan gambaran yang lebih jelas.

2. Display Data (Tampilan Data)

Menurut Sugiyono (2013: 341), "dalam penelitian kualitatif, penyajian data bisa dilakukan dalam bentuk uraian singkat, bagan, hubungan antar kategori, flowchart dan sejenisnya". Pada tahap ini peneliti menyajikan data-data yang telah direduksi ke dalam laporan yang sistematis.

3. Conclusion Drawing/Verification

Langkah ketiga dalam analisis data adalah Conclusion Drawing/Verification, di mana Miles dan Huberman (1984: 22) menjelaskan bahwa, "from beginning of data collection, the qualitative analyst is beginning to decide what things mean". Simpulan awal yang dikemukakan masih bersifat sementara, dan akan berubah bila tidak ditemukan bukti-bukti yang kuat pada tahap pengumpulan data berikutnya, tetapi apabila simpulan yang dikemukakan pada tahap awal, didukung oleh bukti-bukti yang valid dan konsisten saat penelitian kembali ke lapangan mengumpulkan data, maka akan diperoleh simpulan yang kredibel.

4. Analisis SWOT

SWOT merupakan kependekan dari kekuatan (strengths), kelemahan (weakness), peluang (opportunities), dan ancaman (threats) dari lingkungan internal dan eksternal organisasi. Menurut Jogiyanto (2005: 46), SWOT digunakan untuk menilai kekuatan- 
kekuatan dan kelemahan-kelemahan dari sumber-sumber daya yang dimiliki perusahaan dan kesempatankesempatan eksternal dan tantangantantangan yang dihadapi.

Metode analisis SWOT terdapat dua bentuk pengamatan terhadap lingkungan, yaitu analisis lingkungan eksternal dan analisis lingkungan internal. Analisis lingkungan eksternal terdiri dari variabelvariabel (peluang dan ancaman) yang berada di luar organisasi dan tidak secara khusus ada dalam pengendalian jangka pendek dari manajemen puncak. Variabelvariabel tersebut membentuk keadaan dalam organisasi di mana organisasi hidup. Sedangkan lingkungan internal terdiri dari variabel-variabel (kekuatan dan kelemahan) yang ada di dalam organisasi tetapi biasanya tidak dalam pengendalian jangka pendek dalam manajemen puncak. Variabel-variabel tersebut membentuk suasana di mana pekerjaan dilakukan. Variabel-variabel tersebut meliputi struktur, budaya, dan sumber daya organisasi. Secara sederhana, Utomo (2000: 11) menggambarkan lingkungan internal, yaitu Strength, weakness, dan lingkungan eksternal oppurtunity, threat beserta kedua sisi positif dan negatifnya.

Analisis SWOT merupakan identifikasi berbagai faktor internal dan faktor eksternal organisasi yang memengaruhi potensi dan daya saing organisasi secara sistematis dan menyesuaikan di antara faktor tersebut untuk merumuskan strategi organisasi. Berdasarkan penjelasan di atas, maka penulis merumuskan sebagai berikut.

- Strength merupakan faktor internal yang mendukung organisasi dalam mencapai tujuannya. Faktor ini mencerminkan situasi atau kondisi yang merupakan kekuatan dari organisasi atau program pada saat ini, seperti sumber daya, keahlian, atau kelebihan lain yang mungkin diperoleh berkat sumber keuangan, citra, keunggulan di pasar, serta hubungan baik antara buyer dengan supplier.

- Weakness merupakan faktor internal yang menghambat organisasi dalam mencapai tujuan. Faktor ini mencerminkan situasi atau kondisi yang merupakan kelemahan dari organisasi atau program saat ini, misalnya: fasilitas yang tidak lengkap, kurangnya sumber keuangan, kemampuan mengelola, keahlian pemasaran dan citra perusahaan.

- Opportunity merupakan faktor eksternal yang mendukung organisasi dalam mencapai tujuan. Faktor ini mencerminkan situasi atau kondisi yang merupakan peluang di luar organisasi dan memberikan peluang berkembang bagi organisasi di masa depan, seperti perubahan kebijakan, perubahan persaingan, perubahan teknologi dan lain-lain.

- Threat merupakan faktor eksternal yang menghambat organisasi dalam mencapai tujuan.. Faktor ini mencerminkan situasi yang merupakan ancaman bagi organisasi yang datang dari luar organisasi dan dapat mengancam eksistensi organisasi di masa yang akan datang. Hal tersebut dapat berupa masuknya pesaing baru, pertumbuhan pasar yang lambat, meningkatnya bargaining power daripada supplier dan buyer utama, perubahan teknologi serta kebijakan baru.

Melihat dari pemahaman-pemahaman di atas, maka penulis berpendapat bahwa analisis SWOT merupakan sebuah proses untuk menghasilkan informasi yang dapat membantu organisasi dalam menyesuaikan antara tujuan, program, dan kapasitas organisasi terhadap lingkungan sosial di sekitarnya. Dengan analisis SWOT ini, maka diharapkan organisasi mampu untuk: 1) Mengetahui kelebihan dan kelemahan yang dimiliki organisasi; 2) Menganalisis 
prospek organisasi dalam melaksanakan setiap program yang dimilikinya guna mencapai tujuan organisasi; 3) Menyiapkan organisasi untuk siap dalam menghadapi permasalahan-permasalahan yang terjadi; dan 4) Menyiapkan organisasi untuk menghadapi adanya kemungkinan dalam perencanaan pengembangan di dalam organisasi.

Setelah melakukan analisis SWOT dan mengidentifikasi faktor pendukung, faktor penghambat, faktor peluang dan faktor ancaman, maka selanjutnya dibuat matriks SWOT. Menurut David (2010: 327) menjelaskan bahwa: "matriks SWOT merupakan sebuah alat pencocokan yang penting dan membantu para manajer mengembangkan empat jenis strategi: Strategi SO (kekuatan-peluang), Strategi WO (kelemahan-peluang), Strategi ST (kekuatan-ancaman), dan Strategi WT (kelemahan-ancaman)." Dan Matriks SWOT juga berfungsi untuk menganalisis lebih lanjut strategi apa yang mungkin diambil dan dijadikan landasan dalam penetapan perencanaan strategis. Identifikasi ini menggunakan matriks SWOT yang terdiri dari 4 sel. Setiap sel akan menghasilkan strategi yaitu strategi SO, strategi ST, strategi WO, dan strategi WT.

Selanjutnya menarik simpulan sebagaimana yang dikemukakan oleh Arikunto (2010: 342) bahwa "menarik simpulan penelitian harus mendasarkan diri atas semua data yang diperoleh dalam kegiatan penelitian". Penarikan simpulan merupakan intisari dari bagian terpenting yang dihasilkan oleh peneliti melalui kegiatan penelitiannya.

\section{HASIL DAN PEMBAHASAN}

\section{Peningkatan Kualitas Sumber Daya Aparatur ASN di Kabupaten Sumedang}

Sebagai langkah strategis dalam membangun pemerintahan agar lebih efektif dan efisien guna melakukan perbaikan, pembaharuan dan perubahan mendasar terhadap penyelenggaraan pemerintah dengan delapan area perubahan yaitu 1) organisasi; 2) Tata laksana; 3) peraturan perundang-undangan; 4) sumber daya manusia aparatur; 5) pengawasan; 6) akuntabilitas; 7) pelayanan publik; dan 8) pola pikir (mind set) dan budaya kerja (culture set) aparatur, sebagai bentuk reformasi birokrasi, dalam rangka meningkatkan Kualitas Sumber Daya Aparatur ASN daerah.

Adapun program Peningkatan Kualitas Sumber Daya Aparatur ASN di Kabupaten Sumedang yang dilakukan di antaranya telah mengikutsertakan setiap aparat untuk melanjutkan pendidikan yang lebih tinggi (program pasca sarjana) sebanyak 2 orang, mengikuti pendidikan dan latihan (Diklat), di mana realisasinya dalam tiga tahun terakhir (2012-2014) berjumlah 8 orang, bimbingan teknis (Bintek) sebanyak 10 orang.

Di samping itu dalam rangka meningkatkan disiplin aparatur, dilakukan pembinaan mental dan kepribadian yang diselenggarakan rutin satu kali sebulan, serta adanya pertemuan rapat staf yang dilakukan oleh sub unit organisasi (tiap bidang) dilakukan semingu sekali. Sementara untuk implementasi peraturan mengenai disiplin pegawai, dilakukan dengan menerapkan sanksi yang tegas kepada setiap aparat yang melanggar aturan di mana terdapat 3 orang pegawai yang diberikan sanksi disiplin yaitu melalui teguran tertulis.

Persoalan tersebut dijelaskan oleh Kepala Sub Bagian Kepegawaian dan Umum kepada penulis, pada Jumat, 1 Juni 2018 bahwa:

"Mayoritas pegawai yang memiliki dengantingkatpendidikanSLTAsehingga, sangat sulit untuk mengharapkan tugas dan fungsi yang dilaksanakan berhasil dengan baik, dalam menyelenggarakan layanan sipil. Oleh sebab itu, dibutuhkan adanya upaya dari pemerintah daerah 
untuk mengembangkan SDM sehingga Kualitas Sumber Daya Aparatur ASN dapat ditingkatkan".

Berdasarkan penjelasan di atas, dapat disimpulkan bahwa Peningkatan Kualitas Sumber Daya Aparatur ASN di Kabupaten Sumedang telah dilaksanakan namun belum terselenggara dengan baik. Hal itu disebabkan karena kurangnya kemampuan yang dimiliki oleh aparat dalam melaksanakan tugas dan fungsinya, terutama dalam memberikan layanan sipil kepada masyarakat yang membutuhkan jasa layanan. Di samping itu masih terdapat aparat yang kurang disiplin, yang terlihat dari seringnya aparat yang masuk kantor tidak tepat waktu, dan pulang cepat, sehingga berdampak pada penyelenggaraan layanan yang belum optimal.

\section{Faktor-Faktor yang Memengaruhi Peningkatan Kualitas Sumber Daya Aparatur ASN}

Faktor yang memengaruhi peningkatan Sumber Daya Aparatur ASN dengan landasan teori yang dikemukakan oleh Koswara (2015: 287) yang menyatakan bahwa: kemampuan profesional dan keterampilan teknis para pegawai yang termasuk kepada unsur staf dan pelaksana di lingkungan pemerintah daerah ini sangat diperlukan agar manajemen pemerintahan dalam otonomi daerah dapat berlangsung secara efektif dan efisien. yang diperlukan tidak hanya jumlahnya yang cukup, tetapi juga kualitas para pegawai yang harus diukur dengan melihat latar belakang pendidikan, keterampilan, pengalaman kerja, jenjang kepangkatan dan status kepegawaian. dengan demikian pengukuran sesuai hal tersebut di atas meliputi: 1) tingkat pendidikan, 2) pengalaman, 3) pengetahuan, dan 4) keterampilan, yang diperlukan oleh setiap aparatur guna melaksanakan tugas dan fungsinya dalam rangka pencapaian tujuan organisasi.

\section{- Tingkat Pendidikan}

Tingkat Pendidikan dapat menunjang peran serta aparatur pemerintah dalam pengelolaan kekuasaan pemerintahan melalui berbagai aktivitas yang diselenggarakan harus dapat berperilaku dan bertindak secara benar dan sesuai dengan nilai-nilai yang berlaku di masyarakat sehingga masyarakat benar-benar merasa dilayani dengan baik. Sehubungan dengan maksud tersebut, maka aparatur sebagai tulang punggung dalam setiap aktivitas organisasi pemerintahan daerah perlu diberdayakan, dalam arti ditempatkan sesuai dengan tingkat pendidikan dan kemampuan yang dimiliki dalam suatu unit organisasi.

Berdasarkan hasil pengamatan yang dilakukan oleh penulis terhadap aparat yang bertugas menyelenggarakan layanan sipil yang berjumlah 12 orang, terlihat bahwa tingkat pendidikan yang dimiliki umumnya setara dengan SLTA. Sebagaimana dijelaskan oleh Kepala Bidang Pelayanan Pendaftaran Penduduk, dari hasil wawancara dengan penulis pada Jumat, 15 Juni 2018, bahwa "Umumnya aparat yang dimiliki dan yang menyelenggarakan tugas-tugas layanan akteakte umumnya memiliki tingkat pendidikan SLTA. Untuk itu kami berupaya untuk meningkatkan kemampuan yang dimiliki setiap aparat baik melalui Diklat struktural dan fungsional, dan juga diikutsertakan pada tugas belajar".

Penjelasan di atas, memberikan indikasi bahwa seorang aparat yang memiliki kemampuan dapat dikenali melalui bagaimana ia melaksanakan tugas dan fungsi yang diemban. Menurut Notoatmodjo (2008: 96) bahwa "pendidikan adalah upaya untuk mengembangkan sumber daya manusia terutama untuk pengembangan aspek intelektual dan kepribadian manusia".

Dengan demikian, melalui tingkat pendidikan yang dimiliki setiap aparat, baik secara individu maupun kelompok mampu menganalisis dan mengembangkan 
mekanisme kerja yang lebih efektif dalam melaksanakan tugas dan fungsinya secara baik. Hal itu terlihat dari berbagai aktivitas yang diselenggarakan, terutama dalam memberikan pelayanan akta catatan sipil, yang masih perlu ditingkatkan lagi karena tingkat pencapaiannya masih belum optimal.

Fenomena belum baiknya proses penyelenggaraan pemerintahan yang baik sebagaimana yang disampaikan, seharusnya menjadi perhatian dari para pimpinan guna memperhatikan apa saja yang diinginkan oleh para bawahan, dan bukan hanya melalui sistem perintah. Padahal yang diinginkan oleh para bawahan adalah bagaimana mereka dihargai oleh pimpinan, setelah tanggung jawab yang diberikan. Penghargaan yang diberikan oleh pimpinan kepada para bawahannya, dapat dilakukan dalam berbagai bentuk, di antaranya ucapan terima kasih dan memberikan motivasi agar pada pegawai lebih giat dalam bekerja.

Kebijaksanaan yang ditempuh pimpinan tersebut dianggap oleh setiap aparat merupakan hal yang sangat menguntungkan, karena merupakan salah satu faktor pendorong bagi aparat untuk lebih giat dalam bekerja, dan lebih kreatif, sehingga dapat menyelesaikan tugas tepat pada waktunya dan kesalahan dan kekeliruan administratif dapat diminimalkan.

Kesediaan pimpinan untuk memberdayakan bawahan dengan dengan cara yang demikian akan memberikan motivasi dari para bawahan guna meningkatkan Kualitas Sumber Daya Aparatur ASN bagi setiap masyarakat yang membutuhkan jasa layanan. Oleh sebab itu dalam melaksanakan pekerjaannya, para pegawai diharapkan senantiasa lebih kreatif dalam Pelaksanaan tugas guna menghasilkan produk layanan yang berkualitas.

Sebagaimana yang dikemukakan oleh Sedarmayanti (2004: 153) bahwa "kreativitas merupakan penyatuan pengetahuan dari berbagai bidang pelayanan yang berlainan untuk menghasilkan ide baru yang lebih baik". Kreativitas merupakan kemampuan dan kecakapan untuk membangun atau menciptakan sesuatu yang baru, misalnya berupa hubungan atau struktur yang baru atau dapat pula berupa cara baru untuk memecahkan suatu masalah.

Realitas tersebut di atas, perlu dicermati melalui langkah-langkah strategis dalam mengembangkan setiap potensi dan kemampuan yang dimiliki setiap aparat dalam penyelenggaraan tugas dan fungsinya. Upaya meningkatkan kualitas harus dimulai dengan meningkatkan dan mengembangkan kemampuan setiap individu dalam organisasi. Pengembangan sumber daya aparat diarahkan kepada jalur profesional, guna meningkatkan kualitas sesuai dengan kebutuhan organisasi pemerintahan.

Tuntutan peningkatan kemampuan seperti kursus-kursus bagi para pegawai pelaksana secara berkesinambungan, adalah suatu keharusan. Namun dalam realitanya Diklat dan kursus lebih banyak ditujukan kepada unsur pimpinan, sehingga menimbulkan kesenjangan pengetahuan antara para pimpinan dengan bawahannya.

Hal itu sebagaimana dikemukakan oleh Kepala Sub Bagian Perencanaan Program kepada penulis dari hasil wawancara pada Senin, 11 Juni 2018 bahwa:

"Tuntutan kursus atau penataran
bersifat teknis dalam rangka
meningkatkan kemampuan aparat
dari aspek tingkat pendidikan, dengan
menambah kemampuan, namun hal itu
belum terlaksana dengan baik". Padahal
melalui peningkatan pendidikan dan
pelatihan teknis, akan mengarah pada
spesialisasi fungsionalisme dari setiap
aparat guna membentuk setiap individu
dalam meningkatkan kualitas pelayanan
yang diberikan.

Dukungan manajerial untuk inovasi, sangat menentukan bagi seluruh individu untuk mengembangkan mengembangkan 
dan mengimplementasikan ide mengenai cara baru yang lebih baik dalam mengerjakan berbagai hal. Oleh sebab itu, adanya dorongan hasrat dan tekat untuk mencari, menemukan dan menggunakan metode dan cara baru, guna melakukan terobosan tanpa harus terpaku tugas rutin, terutama dalam memberikan layanan sesuai keinginan dan harapan masyarakat.

Berdasarkan penjelasan di atas dapat disimpulkan bahwa proses Peningkatan Kualitas Sumber Daya Aparatur ASN di Kabupaten Sumedang dari aspek tingkat pendidikan belum terselenggara dengan baik. Hal itu disebabkan karena kurang tersedianya sumber daya yang memiliki tingkat pendidikan yang memadai, karena umumnya tingkat pendidikan yang dimiliki organisasidinasmasihdidominasioleh aparat yang memiliki tingkat pendidikan setingkat SLTA. Konsekuensi tersebut memberi dampak terhadap proses penyelenggaraan layanan sipil yang dilakukan oleh aparat belum diselenggarakan secara optimal.

\section{- Pengalaman}

Peningkatan kualitas melalui pengalaman akan menambah produktivitas kinerja pegawai dan tujuan organisasi akan terwujud, Perkembangan kehidupan masyarakat yang semakin kompleks dan dinamis yang mengarah kepada era pengetahuan, menyebabkan tuntutan akan penyelenggaraan pelayanan yang diberikan birokrasi pemerintahan, juga berubah.

Untuk itu dibutuhkan kecakapan dari setiap aparat dalam melaksanakan tugas, yang berarti dibutuhkan kemampuan dalam menguasai berbagai hal yang berhubungan dengan bidang pekerjaannya, bagi setiap aparatur yang ada di lingkungan organisasi pemerintah daerah. Artinya bahwa setiap program kerja yang ditetapkan organisasi, akan diimplementasikan sesuai dengan metode dan standar prosedur kerja, yang didukung oleh iklim suasana kerja yang kondusif yang lebih berdaya guna dan berhasil guna.

Dalam rangka meningkatkan produktivitas kerja dibutuhkan ketekunan dan faktor kenyamanan kerja dari setiap sumber daya dalam melaksanakan pekerjaannya, sebagaimana dikemukakan oleh Siagian (2008: 109) bahwa "Suatu birokrasi pemerintahan dituntut bekerja dengan tingkat efisiensi, efektivitas dan produktivitas yang setinggi mungkin, dan memberikan pelayanan yang sebaik mungkin pula". dengan tingkat efisiensi dan efektivitas yang tinggi, merupakan dambaan dari segenap masyarakat yang membutuhkan jasa layanan publik (sipil). Karena dari aspek tersebut, kepedulian setiap aparatur pada Kualitas Sumber Daya Aparatur ASN yang diberikan dapat diperlihatkan, sebaliknya jika terdapat ketidakpedulian aparat dalam melaksanakan tugas, maka perlu disikapi penyebab dari ketidakmampuan tersebut.

Menyikapi persoalan tersebut di atas, dibutuhkan adanya kemampuan aparatur baik dari pengalaman kerja atau kesempatan untuk maju merupakan perangsang kuat bagi tenaga kerja untuk bekerja lebih giat dan lebih bergairah. Program pelatihan dan pengembangan yang sistematis memberikan motivasi dan memberikan kesempatan kepada setiap aparat untuk meningkatkan kemampuan dan mencapai posisi yang memiliki tanggung jawab lebih besar.

Sebagaimana dijelaskan kepada penulis oleh Badan Kepegawaian dan Pengembangan Sumber Daya Manusia Kabupaten Sumedang, pada Selasa, 12 Juni 2018 bahwa:

Sebenarnya di samping kami memiliki kekurangan aparat dari aspek tingkat pendidikan yang sebagian besar setingkat SLTA, Badan Kepegawaian juga memiliki aparat yang sebagian besar kurang memiliki pengalaman karena memiliki masa kerja yang sedikit, karena sebagian besar aparat masih tergolong pegawai baru, yang rata-rata memiliki 
masa kerja di bawah lima tahun. Hal itu memberi dampak terhadap proses penyelenggaraan pemerintahan..

Berdasarkan penjelasan yang disampaikan di atas mengindikasikan bahwa proses Peningkatan Kualitas Sumber Daya Aparatur ASN di Kabupaten Sumedang sebagai bagian dari upaya meningkatkan Kualitas Sumber Daya Aparatur ASN telah dilaksanakan, namun belum terselenggara dengan baik. Hal itu karena sebagian besar aparat yang bertugas hanya berpendidikan lulusan SLTA, dan umumnya kurang berpengalaman, karena rata-rata pegawai memiliki masa kerja kurang dari lima tahun. Padahal pengalaman yang dimiliki seorang aparat akan mudah menganalisis dan mencari jalan yang terbaik dalam melaksanakan pekerjaan sesuai tugas dan fungsinya.

Kemampuan atau keahlian yang didasari oleh pengalaman, sesuai bidang tugas dan fungsinya, merupakan salah satu aspek dalam meningkatkan Kualitas Sumber Daya Aparatur ASN kepada setiap warga masyarakat yang membutuhkan jasa layanan. Namun demikian, dengan kemampuan berupa pengalaman yang dimiliki saja belum cukup bagi seseorang aparat untuk dapat menyelenggarakan tugas dan fungsinya dengan baik, tetapi juga harus dibarengi dengan disiplin dalam bekerja. Disiplin bagi seseorang aparatur demikian penting, karena terkait dengan ketaatan dan kepatuhan terhadap berbagai aturan dan ketentuan yang berlaku dalam organisasi dinas.

\section{- Pengetahuan}

Proses menyelenggarakan tugas dan fungsi, setiap aparat pastinya memiliki harapan untuk mencapai kesuksesan. Harapan tersebut merupakan keadaan individu yang terangsang dihubungkan dengan suatu yang relevan atau sesuai keberhasilan seseorang dalam mencapai hasil yang paling baik sesuai visi dan misi organisasi. Semakin tinggi harapan untuk sukses dan kuat hati untuk mengatasi kegagalan adalah kondisi utama untuk mencapai hasil yang lebih baik. Oleh sebab itu peran pimpinan organisasi dalam menempatkan setiap aparat baik pegawai baru, maupun pegawai lama dalam suatu posisi tertentu, sesuai dengan struktur organisasi, perlu memperhatikan latar belakang pengetahuan yang dimiliki secara objektif sebagai bentuk pola karier.

Penjelasan di atas, Rasyid (2007: 81) menyampaikan bahwa "Proses penempatan seseorang dalam jabatan birokrasi belum sepenuhnya didasarkan pada suatu pedoman tentang pola karier yang jelas dan dipegang secara Objektif." Asumsinya bahwa dalam menempatkan seseorang aparatur, haruslah memperhatikan pengetahuan yang dimiliki, sehingga mampu bekerja dan memberikan hasil sesuai yang diinginkan organisasi. Kemampuan melalui pengetahuan sesuai bidangnya, bisa jadi merupakan hal yang penting untuk mencapai tujuan organisasi. Tetapi akan menjadi masalah jika seseorang aparat sebenarnya memiliki kemampuan dan pengetahuan, tetapi tidak dilibatkan dan dimanfaatkan secara optimal.

Kenyataan yang terjadi di lapangan menunjukkan bahwa masih terdapat sebagian aparat yang memiliki potensi dengan dasar pengetahuan yang dimiliki, namun belum dimanfaatkan secara optimal, terutama dalam tugas-tugas pelayanan. Hal itu sebagaimana dijelaskan oleh Kepala Bidang Pengelolaan dan dan Dokumen Kepegawaian, pada Senin, 22 Juni 2018 kepada penulis bahwa:

Sebenarnya pada unit organisasi Badan Kepegawaian, terdapat beberapa aparat yang memiliki potensi dalam menyelenggarakan tugas dan fungsi, namun kemampuan yang dimiliki itu belum dimanfaatkan secara maksimal, sehingga aparat menjadi kurang peduli terhadap proses penyelenggaraan 
tugas dan fungsi yang diberikan. Oleh sebab itu persoalan tersebut haruslah disikapi oleh para pimpinan organisasi untuk mengambil langkah-langkah, sehingga masalah yang ditimbulkan tersebut tidak berdampak lebih jauh dalam penyelenggaraan tugas dan fungsi terutama dalam menyelenggarakan layanan kepada masyarakat.

Dengan memiliki tingkat pengetahuan yang tinggi dari setiap aparat di lingkungan Badan Kepegawaian, maka diharapkan akan mewujudkan proses penyelenggaraan pemerintahan dengan baik dan efektif, dalam arti mampu menyelenggarakan pemerintahan secara optimal.

Sumber daya aparatur sebagai faktor yang dominan dalam organisasi pemerintahan daerah hanya akan menjadi nyata dan berguna secara riil, manakala sumber daya tersebut telah dibekali atau memiliki tingkat pengetahuan dan kemampuan yang memadai. Besarnya peranan pengetahuan yang dimiliki aparatur dalam mendukung peyelenggaraan tugas dan fungsi dalam suatu organisasi, dimaksudkan untuk memahami kondisi internal dalam memaksimalkan kinerja organisasi.

Pemahaman terhadap pembelajaran organisasi adalah sesuatu yang baru yang kadang masih sering disalahtafsirkan hanya sebagai upaya-upaya pelatihan maupun pengembangan kemampuan lembaga dan aparat. Sebenarnya pembelajaran organisasi membawa misi di mana yang dilakukan lebih pada merubah hakikat manusia atau individu aparat untuk sadar akan potensi yang dimilikinya. Pembelajaran yang berkesinambungan merupakan inti dari organisasi pembelajaran. Kekuatan organisasi pembelajaran lebih kepada kemampuan organisasi untuk menilai siapa dirinya, siapa orang-orang di dalamnya dalam menyelenggarakan pemerintahan yang baik dan berkualitas.

Sesuai hasil pengamatan yang dilakukan penulis di lapangan memperlihatkan bahwa, pada dasarnya tingkat pengetahuan yang dimiliki oleh aparat di Badan Kepegawaian dan Pengembangan Sumber Daya Manusia Kabupaten Sumedang belum memadai. Sebagaimana terungkap dari hasil wawancara dengan Kepala Dinas, pada Senin, 4 Juni 2018 yang menjelaskan bahwa:

Disadari bahwa kami dihadapkan pada persoalan yang cukup sulit, di satu sisi kami diwajibkan untuk meningkatkan Kualitas Sumber Daya Aparatur ASN pemerintahan kepada masyarakat melalui pelayanan prima. Namun di sisi lain, kami dihadapkan pada kurangnya kualitas sumber daya aparatur yang memiliki tingkat pengetahuan yang memadai, sehingga berdampak pada penyelenggaraan layanan sipil yang belum maksimal.

Aktualisasi terhadap pengetahuan yang dimiliki yang dimiliki setiap aparatur pada prinsipnya diarahkan pada, bagaimana dengan tingkat kemampuan yang dimiliki dapat memberikan pelayanan yang terbaik kepada masyarakat yang membutuhkan jasa layanan sipil. Oleh sebab itu setiap aparat/pegawai perlu memiliki pemahaman (frame of reference) tentang visi misi organisasi, sebagai landasan berpijak dalam melaksanakan tugas dan fungsinya. Setiap aparat sepatutnya memiliki wawasan terhadap konsep yang berkaitan dengan pelayanan, yang berkaitan dengan fungsi dan tugas organisasinya. Sebagaimana pendapat Siagian (2009: 58) bahwa "dalam konteks pelaksanaan tugas dan fungsi pelayanan pemerintahan, pengetahuan merupakan keterampilan dalam menilai tingkat kemampuan kerja seorang pegawai".

Pendapat yang disampaikan pakar di atas, memberikan gambaran bahwa pengetahuan merupakan salah satu aspek penting dalam pelaksanaan tugas dan fungsi organisasi pemerintahan, terutama yang berhubungan dengan pelayanan publik (sipil). Oleh sebab itu pengetahuan yang 
dimiliki seorang aparat, menjadi landasan untuk menyelenggarakan tugas dan fungsi dalam organisasi. Sebaliknya, jika seseorang aparat kurang memiliki pengetahuan terhadap tugas dan fungsi yang diemban, niscaya tugas yang dilaksanakan tidak dapat diselenggarakan secara efektif dan efisien.

Pengetahuan yang dimiliki seseorang aparat pada hakikatnya merupakan pemahaman akan informasi itu sendiri, karena melalui pengetahuan akan memberikan landasan yang lebih kuat terhadap hal apa yang semestinya dikerjakan. Sebagaimana dikemukakan Suriasumantri (1998: 67) bahwa "pengetahuan pada hakikatnya merupakan produk kegiatan berpikir dalam pikiran manusia tentang berbagai informasi yang diterima".

Dengan demikian pengetahuan yang dimiliki dari setiap aparat dapat dijadikan tolok ukur dalam menilai tingkat perilaku seorang aparatur yang dilandasi dengan disiplin kerja dalam melaksanakan tugas dan tanggung jawab yang diberikan kepadanya, terutama dalam memberikan pelayanan yang terbaik kepada masyarakat.

Kemudian, tingkat pengetahuan yang dimiliki setiap aparat merupakan hasil rujukan yang terkait dengan kemampuan atau kompetensi dalam mengolah dan memahami suatu informasi serta pengalaman yang diperoleh melalui proses hasil pembelajaran. Oleh sebab itu, Badan Kepegawaian dan Pengembangan Sumber Daya Manusia Kabupaten Sumedang sebagai organisasi publik yang menyediakan dan menyelenggarakan pelayanan publik, senantiasa berupaya memaksimalkan pengetahuan yang dimiliki oleh setiap aparatur, dengan melakukan proses pembelajaran untuk mendukung keberhasilan organisasi mencapai tujuan yang diharapkan, terutama dalam memperoleh pemahaman tentang konsep dan teknis dalam memberikan layanan kepada masyarakat yang membutuhkan.
Siagian (2008: 58) menyatakan bahwa "dalam pembentukan perilaku administrasi pegawai, diperlukan pengetahuan secara mendalam". Melalui pengetahuan yang dimiliki seorang aparat, baik secara individu maupun kelompok mampu menganalisis dan mengembangkan mekanisme kerja yang lebih efektif dalam melaksanakan tugas dan fungsinya secara baik. Seperti dalam pandangan Widayana (2005: 13) bahwa "pengetahuan adalah penerapan informasi yang dilengkapi dengan pemahaman pola hubungan dari informasi disertai pengalaman, baikindividu maupun kelompok dalam organisasi sehingga diyakini dapat langsung digunakan untuk mengambil suatu keputusan untuk bertindak"

Namun demikian, realitas yang ditemui memperlihatkan bahwa aparat sering mengalami keterlambatan dalam menyelesaikan tugas dan dan fungsi yang diberikan. Hal itu sebagaimana dijelaskan oleh Kepala Seksi Pengelolaan Data dan Dokumen kepegawaian kepada penulis, pada rabu 16 Juni 2018 bahwa:

Sesuai struktur organisasi, tingkat pengetahuan yang dimiliki aparat dinilai cukup memadai bagi aparat yang memiliki jabatan, karena seluruhnya memiliki pengetahuan setingkat sarjana, namun bagi aparat yang bertugas memberikan pelayanan, dimiliki pengetahuan yang masih tergolong minim. Persoalan tersebut yang menyebabkan seringnya terjadi keterlambatan dalam menyelesaikan tugastugas yang diberikan, terutama dalam memberikan pelayanan kepada masyarakat yang membutuhkan jasa layanan sipil.

Upaya peningkatan pengetahuan yang dimiliki setiap aparat, dapat dilakukan melalui program tugas belajar, baik untuk program strata I (Sarjana) ataupun Strata II (Pasca Sarjana) kepada aparat yang memiliki potensi untuk dikembangkan. Dengan mengikutsertakan aparat dalam program tugas belajar tersebut, di satu sisi setiap 
aparat merasa diperhatikan oleh pimpinan organisasi yang lebih tinggi, di sisi yang lain dengan pengetahuan yang dimiliki aparatur tersebut diharapkan tugas dan tanggung jawab yang diberikan kepadanya dapat terlaksana dengan baik. Namun demikian kesempatan yang diberikan kepada setiap aparat untuk mengembangkan pengetahuan masih sangat terbatas dalam lingkungan organisasi Badan Kepegawaian dan Pengembangan Sumber Daya Manusia Kabupaten Sumedang maupun pemerintah daerah masih memiliki keterbatasan anggaran untuk hal tersebut.

Aspek pengetahuan yang dimiliki setiap aparatur dalam melaksanakan tugas pokok maupun fungsi, menjadi dasar untuk menentukan standar kinerja yang meliputi semua aspek penting dari pekerjaan yang bersama-sama berperan untuk mencapai keberhasilan tujuan dari pada organisasi dinas secara keseluruhan. Oleh sebab itu Badan Kepegawaian dan Pengembangan Sumber Daya Manusia Kabupaten Sumedang sebagai sebuah organisasi pemerintah daerah, perlu senantiasa berupaya untuk meningkatkan pengetahuan yang dimiliki setiap aparatur, sehingga dapat memberikan pelayanan yang berkualitas sekaligus dapat meningkatkan kinerja organisasi.

Berdasarkan penjelasan di atas dapat disimpulkan bahwa proses Peningkatan Kualitas Sumber Daya Aparatur ASN di Kabupaten Sumedang dalam meningkatkan Kualitas Sumber Daya Aparatur ASN dari aspek pengetahuan belum terlaksana optimal. Hal itu disebabkan karena kurangnya pemahaman terhadap tugas dan fungsi yang diberikan menyebabkan program-program yang telah disusun oleh masing-masing sub unit organisasi hasilnya kurang memuaskan. Di samping itu kurang adanya perhatian dari pimpinan dalam memanfaatkan segenap potensi yang dimiliki aparat, sehingga tugas dan fungsi yang diselenggarakan belum dapat dicapai secara optimal.

\section{- Keterampilan}

Keterampilan (skill) sebagai salah satu aspek yang mengonstruksi kemampuan (kompetensi) aparatur untuk menyelenggarakan layanan yang berkualitas. Sebagaimana Spencer and Spencer (1993: 9-10) memberikan pandangan tentang "lima tipe karakteristik yang mendasar dari kompetensi yaitu knowledge, information a person has in specific content areas".

Pendapat ini menyatakan bahwa kemampuan berupa pengetahuan seorang aparat dalam melaksanakan tugas pokoknya memberikan pelayanan kepada masyarakat. Kemampuan sebagai suatu adequacy untuk tugas atau possession yang memerlukan pengetahuan, atau dengan kata lain suatu kemampuan yang di dalamnya berupa pengetahuan yang dimiliki individu dalam melaksanakan tugas. Selain pendapat Spencer, yang mengemukakan tentang skill sebagai kemampuan yang terdapat di dalam kompetensi seseorang, Cohen (1980: 173) berpendapat bahwa "competencies are the areas of knowledge, ability and skill that increase and individual's effectiveness in dealing with the world".

Upaya meningkatkan keterampilan sebagai bentuk pengembangan sumber daya aparat, selain merupakan fakta bahwa setiap aparat pemerintahan membutuhkan knowledge, keahlian dan skill yang lebih baik (Samsudin, 2005;207). Hal itu juga dimaksudkan untuk membantu aparat dalam mempersiapkan diri menghadapi dinamika kebutuhan yang mendukung proses pelaksanaan tugas dan fungsinya dengan memanfaatkan teknologi. Peningkatan keterampilan dapat dilakukan melalui kegiatan pelatihan sebagai bagian dari proses pembelajaran, yang di dalamnya terkandung pemahaman secara implisit, yang memungkinkan setiap aparatur mampu memecahkan masalah yang dihadapi.

Keterampilan yang ditingkatkan di antaranya adalah untuk penguasaan 
terhadap tugas dan fungsi dalam proses penyelenggaraan layanan sipil. Oleh sebab itu keberhasilan setiap aparat dapat dinilai dari tingkat keterampilan yang dimiliki dalam melaksanakan tugas dan fungsi organisasi, sesuai metode/prosedur dalam menyelesaikan setiap pekerjaan yang dibebankan kepadanya,

Kemampuan bekerja sesuai tugas pokok dan fungsi merupakan kesempatan yang diharapkan untuk mencapai sasaran hasil sebagaimana yang diharapkan organisasi. Sementara pemahaman akan fungsi kerja merupakan artikulasi nilai yang dimiliki oleh pegawai melalui motivasi yang dimiliki dalam menyelenggarakan peningkatan kualitas Sumber Daya Aparatur.

Kemudian Keterampilan yang dikemukakan oleh Siagian (2006: 56) diartikan sebagai "kemampuan teknis untuk melakukan sesuatu kegiatan tertentu yang dapat dipelajari dan dikembangkan".

Berdasarkan pendapat tersebut di atas, dapat dijelaskan bahwa keterampilan seseorang dalam bekerja akan dinilai dari kemampuannya melaksanakan pekerjaan sesuai metode/prosedur kerja dan kemampuan bekerja sama dalam menyelesaikan pekerjaan. Hal tersebut Guna menciptakan kondisi aktivitas kerja yang lebih berdaya guna dan berhasil guna, kontinu dan terarah bagi setiap aparat, maka aspek yang perlu diperhatikan adalah keterampilan teknis. Dengan memiliki keterampilan teknis, setiap aparat dapat mengerti dan memahami metode dan prosedur dalam melaksanakan semua yang menjadi tugas dan kewajibannya, terutama dalam meningkatkan Kualitas Sumber Daya Aparatur ASN.

Kondisi kurangnya kemampuan teknis yang dimiliki sebagian aparat, sebagaimana yang diungkapkan informan warga masyarakat pada Selasa, 19 Juni 2018 kepada penulis sebagai berikut.

Memang diakui sering terjadi kesalahan yang dibuat aparat pelaksana dalam memberikan layanan akta yang kami urus sehingga, Hal itu memberi kesan bahwa aparat yang ditugaskan untuk memberikan layanan, kurang mengerti dan memahami layanan yang diberikan. Oleh sebab itu kami mengharapkan agar para pegawai perlu ditingkatkan keterampilannya sehingga kesalahan terutama dari segi administrasi dapat diminimalkan dan kalau perlu tidak terjadi lagi.

Ungkapan yang disampaikan oleh masyarakat tersebut di atas, memberikan indikasi bahwa kemampuan di bidang teknis yang dimiliki aparat dalam menyelesaikan tugas dan tanggung jawabnya yang diberikan masih kurang. Hal itu disebabkan karena itu dari jumlah aparat yang melaksanakan tugas memberikan layanan kepada masyarakat, ternyata belum memiliki kemampuan secara teknis di bidang tugas yang menjadi tanggung jawabnya. Dari 12 orang aparat pelaksana yang ditugaskan, baru 2 orang yang telah mengikuti pelatihan teknis guna meningkatkan keterampilan dalam memberikan pelayanan kepada masyarakat, sehingga mutu pelayanan yang diberikan masih rendah.

Kemampuan teknis merupakan bagian dari keterampilan yang dapat dijadikan kriteria dalam menilai keterampilan yang dimiliki oleh aparat yang bersangkutan. Dengan demikian dapat digambarkan bahwa keterampilan seseorang dalam bekerja akan dinilai dari kemampuannya dalam melaksanakan pekerjaan sesuai metode/ prosedur kerja dan kemampuan bekerja sama dalam menyelesaikan tugas dan tanggung jawab yang diberikan. Secara cepat dan tepat dalam menyelesaikan masalah/ keluhan secara tuntas.

Upaya meningkatkan mutu pelayanan harus dimulai dengan meningkatkan dan mengembangkan keterampilan setiap aparat yang memiliki potensi dalam organisasi. Peningkatan Kualitas Sumber Daya Aparatur 
ASN di Kabupaten Sumedang diarahkan kepada jalur profesional, guna meningkatkan kualitas sesuai dengan kebutuhan organisasi pemerintahan. Tuntutan peningkatan kemampuan dan keterampilan seperti kursus-kursus bagi aparat yang memberikan pelayanan kepada masyarakat secara berkesinambungan, adalah suatu keharusan.

Realitas yang ditemui di lapangan menunjukkan bahwa diklat dan kursus lebih banyak ditujukan kepada unsur pimpinan, sehingga menimbulkan kesenjangan kemampuan teknis antara pimpinan dengan stafnya. Tuntutan kursus atau penataran bersifat teknis dalam meningkatkan kemampuan yang dimiliki, dengan menambah keterampilan mereka. Kesemuanya itu mengarah pada spesialisasi fungsionalisme dari setiap aparat guna membentuk setiap personel dalam menyelenggarakan tugas dan fungsinya secara berdaya guna dan berhasil guna.

Mengantisipasi permasalahan tersebut, yaitudengan peningkatan keterampilanteknis itu dapat dilakukan dengan memberikan kesempatan kepada setiap aparat, terutama yang bertugas di bidang pelayanan, melalui pendidikan dan latihan atau kursus yang relevan dengan bidang tugas dari setiap aparat, sehingga proses penyelenggaraan layanan sipil dapat ditingkatkan. Melalui program Diklat diharapkan setiap aparat dapat meningkatkan keterampilannya, serta mampu berpikir secara lebih rasional dan kritis, dan lebih mudah dalam menyelesaikan segala persoalan yang dihadapi,. Namun demikian kesempatan untuk mengikuti pendidikan dan latihan masih sangat terbatas.

Berdasarkan penjelasan di atas dapat disimpulkan bahwa proses Peningkatan Kualitas Sumber Daya Aparatur ASN di Kabupaten Sumedang dalam meningkatkan Kualitas Sumber Daya Aparatur ASN di Badan Kepegawaian dan Pengembangan Sumber Daya Manusia Kabupaten Sumedang dari aspek pengetahuan belum terlaksana dengan Optima..

\section{Strategi Peningkatan Kualitas Sumber Daya Aparatur ASN di Badan Kepegawaian dan Pengembangan Sumber Daya Manusia Kabupaten Sumedang dengan Menggunakan Analisis SWOT.}

Langkah-langkah yang dilakukan dalam strategi Peningkatan Kualitas Sumber Daya Aparatur ASN di Kabupaten Sumedang dalam meningkatkan Kualitas Sumber Daya Aparatur ASN yang diselenggarakan di Badan Kepegawaian dan Pengembangan Sumber Daya Manusia Kabupaten Sumedang, dengan menggunakan analisis SWOT (Strength, Opportunities, Weakness, Threats). Perumusan strategi Peningkatan Kualitas Sumber Daya Aparatur ASN di Kabupaten Sumedang itu dimaksudkan dalam rangka meningkatkan kemampuan sumber daya aparatur, sehingga dapat memberikan pelayanan sipil yang berkualitas kepada segenap masyarakat yang membutuhkan jasa layanan. Di samping itu pula diharapkan tercipta berbagai kondisi lingkungan strategis (eksternal maupun internal) yang dinamis sehingga dapat mencapai pelayanan prima.

Penggunaan analisis SWOT untuk menganalisis Peningkatan Kualitas Sumber Daya Aparatur ASN dimaksudkan dalam rangka mengidentifikasikan berbagai faktor guna merumuskan strategi. Analisis ini didasarkan pada logika untuk memaksimalkan kekuatan (strengths) dan peluang (opportunities), namun secara bersamaan dapat meminimalkan kelemahan (weaknesses) dan ancaman (threats). Kajian dalam penggunaan Analisis SWOT, di dalamnya terdapat empat unsur yang selalu dihadapi dan dimiliki oleh suatu organisasi. Secara internal analisis ini memiliki kekuatan (strengths) dan kelemahan (weaknesses) serta secara eksternal dihadapi berbagai peluang (opportunities) dan ancaman (threats). 


\section{- Kekuatan (Strengths)}

Terdapat beberapa faktor internal organisasi dalam pencapaian tujuan yang menunjang organisasi dalam memberikan pelayanan kepada masyarakat, di mana hasil analisis kekuatan tersebut, yaitu:

a) Kedudukan Badan Kepegawaian dan Pengembangan Sumber Daya Manusia yang strategis dan penting.

b) Struktur organisasi yang lengkap dan proporsional.

c) Hubungan yang baik antara pimpinan dan bawahan.

d) Adanya alokasi dana yang dapat menunjang pelaksanaan program.

e) Keinginan yang kuat dari organisasi untuk meningkatkan kualitas sumber daya aparatur.

f) Penyelenggaraan pendidikan dan latihan, serta bantuan tugas belajar dan ikatan dinas.

g) Adanya kesadaran dari aparat untuk memberikan pelayanan.

\section{- Kelemahan (Weaknesses)}

Adapun beberapa faktor internal organisasi dalam proses pencapaian tujuan yang diinginkan disadari adanya kelemahan yang dapatberpengaruh terhadap keberhasilan pencapaian tujuan dan sasaran dari organisasi, dapat diidentifikasikan sebagai berikut.

a) Uraian tugas yang belum sepenuhnya dilaksanakan oleh aparat.

b) Ketidaksesuaian kemampuan dengan tugas yang diemban.

c) Sumber daya manusia yang terbatas.

d) Sistem pengukuran kehadiran atau presensi masih manual atau belum menggunakan piranti elektronik (software).

e) Sikap mental, motivasi kerja, dan pemahaman terhadap Tupoksi yang masih rendah. f) Sarana dan prasarana masih terbatas.

g) Kurangnya penegakan disiplin pegawai.

\section{- Peluang (Opportunities)}

Melalui hasil analisis yang dilakukan, dapat didefinisikan beberapa peluang sebagai berikut.

a) Penerapan Undang-Undang No. 14 Tahun 2013 tentang Otonomi Daerah.

b) Penerapan Peraturan Pemerintah No. 41 Tahun 2007 tentang Organisasi Perangkat Daerah.

c) Penerapan Peraturan Daerah No. 5 Tahun 2008, tentang Organisasi dan Tata Kerja Dinas Daerah Kabupaten Sumedang.

d) Perlunya Peningkatan Kualitas Sumber Daya Aparatur ASN di Kabupaten Sumedang yang berkualitas.

e) Perlunya peningkatan Kualitas Sumber Daya Aparatur ASN kepada masyarakat.

f) Perlunya pengembangan jaringan informasi dan komunikasi.

\section{- Ancaman (Threats)}

Melalui faktor eksternal selain ada peluang juga terdapat ancaman yang dapat diidentifikasikan sebagai berikut.

a) Kurangnya pengawasan pimpinan organisasi terhadap segenap aparat.

b) Adanya unsur politis dalam penempatan jabatan.

c) Kurangnya kemampuan aparat dalam pengelolaan anggaran bagi Peningkatan Kualitas Sumber Daya Aparatur ASN di Kabupaten Sumedang.

d) Persentase jumlah pegawai yang absen (tidak hadir/mangkir) cukup besar.

e) Kemajuan teknologi komunikasi dan informasi.

f) Rendahnya Kualitas Sumber Daya Aparatur ASN yang diberikan aparat. 


\section{SIMPULAN}

Berdasarkan hasil penelitian dan pembahasan yang telah dipaparkan pada bab sebelumnya, maka penulis dapat menarik simpulan dalam penelitian ini sebagai berikut.

1. Peningkatan Kualitas sumber daya aparatur dalam meningkatkan kualitas layanan sipil telah diselenggarakan oleh Badan Kepegawaian dan Pengembangan Sumber Daya Manusia Kabupaten Sumedang, namun belum terselenggara dengan baik. Hal itu disebabkan karena kurangnya kemampuan yang dimiliki oleh aparat dalam melaksanakan tugas dan fungsinya, terutama dalam menyelenggarakan layanan sipil kepada masyarakat yang membutuhkan jasa layanan. Di samping itu masih terdapat aparat yang kurang kurang disiplin, yang terlihat dari aparat yang masuk kantor tidak tepat waktu, sehingga berdampak pada penyelenggaraan layanan sipil yang belum dicapai secara optimal.

2. Belum baiknya proses Peningkatan Kualitas sumber daya aparatur dalam meningkatkan kualitas disebabkan karena berbagai faktor yaitu.

a. Kurang tersedianya sumber daya yang memiliki Tingkat Pendidikan yang memadai, karena umumnya tingkat pendidikan yang dimiliki Badan Kepegawaian dan Pengembangan Sumber Daya Manusia Kabupaten Sumedang masih didominasi oleh aparat yang memiliki tingkat pendidikan setingkat SLTA, sehingga berpengaruh terhadap penyelenggaraan layanan sipil yang belum dilaksanakan secara optimal.

b. Kurang tersedianya aparat yang memiliki Pengalaman di dalam penyelenggaraan layanan sipil, karena umumnya aparat merupakan pegawai yang memiliki masa kerja sangat terbatas. Hal itu memberi dampak terhadap distribusi pekerjaan yang kurang merata bagi setiap aparat sehingga proses penyelenggaraan layanan belum dilakukan secara optimal.

c. Kurangnya Pengetahuan yang dimiliki aparat sehingga programprogram yang telah disusun oleh masing-masing sub unit organisasi hasilnya kurang memuaskan. Di samping itu kurang adanya perhatian dari pimpinan dalam memanfaatkan segenap potensi pengetahuan yang dimiliki setiap aparat, sehingga tugas dan fungsi yang diselenggarakan belum dicapai secara optimal.

d. Kurangnya Keterampilan atau kemampuan teknis yang dimiliki aparat terhadap tugas dan fungsi, menyebabkan sering terjadi kesalahan administrasi dalam penyelenggaraan layanan yang diberikan. Hal itu ditunjang dengan kurang adanya perhatian pimpinan terhadap proses Peningkatan Kualitas sumber daya aparat melalui Diklat teknis terutama bagi aparat yang memiliki potensi untuk dikembangkan, sehingga memberi dampak terhadap penyelenggaraan layanan sipil yang kurang optimal.

3. Strategi Peningkatan Kualitas sumber daya aparatur dalam meningkatkan kualitas layanan sipil dilakukan melalui analis SWOT, di mana dari hasil analisis SWOT diperoleh gambaran isu strategis yaitu;

a. Menyusun program-program yang dapat mengembangkan sumber daya aparatur dalam meningkatkan Kualitas Sumber Daya Aparatur ASN.

b. Pemberian kesempatan bagi setiap aparat untuk meningkatkan 
pendidikan dan pelatihan, sebagai dengan kemampuan dan keahliannya.

c. Penempatan setiap aparat dalam jabatan sesuai kemampuan yang dimiliki sebagai penggerak organisasi.

d. Meningkatkan motivasi kerja setiap aparat melalui penerapan aturanaturan yang berlaku, dan penerapan uraian tugas yang jelas.

\section{SARAN}

Peningkatan Kualitas sumber daya aparatur dalam meningkatkan kualitas layanan sipil di Badan Kepegawaian dan Pengembangan Sumber Daya Manusia Kabupaten Sumedang, telah dilaksanakan namun belum mencapai hasil yang optimal, sehingga disarankan:

1. Dalam rangka mewujudkan fungsi penyelenggaraan layanan publik (sipil) yang lebih kapabel dan semakin baik, maka faktor-faktor kualitas sumber daya aparatur pemerintah daerah perlu semakin ditingkatkan kemampuannya, dengan mengikutsertakan setiap aparat yang memiliki potensi untuk dikembangkan melalui program tugas belajar maupun izin belajar.

2. Mengingat salah satu kendala yang dihadapi adalah kurangnya kemampuan teknis yang dimiliki oleh aparat pelaksana dalam memberikan layanan sipil, maka perlu ada upaya peningkatan kualitas sumber daya aparatur melalui Pendidikan dan Pelatihan Teknis atau kursus-kursus di bidang pelayanan publik yang dilakukan secara berkesinambungan, sehingga setiap aparat dapat mengerti dan memahami tugas dan fungsi yang dilaksanakan.

3. Perlu adanya perhatian dari pimpinan terhadap setiap aktivitas yang dilakukan para bawahannya sehingga tugas dan fungsi yang dilaksanakan dapat mencapai hasil sebagaimana yang diharapkan. Untuk itu perlu adanya bimbingan dan pembinaan yang dilakukan oleh pimpinan melalui rapat staf yang dilakukan secara rutin, untuk memberikan penyegaran dan pemahaman kepada setiap aparat, sekaligus guna melakukan evaluasi terhadap proses penyelenggaraan tugas dan fungsi yang dilakukan para bawahan, terutama dalam proses penyelenggaraan layanan sipil.

\section{DAFTAR RUJUKAN}

Arikunto. 2010. Prosedur penelitian: Suatu Pendekatan Praktik. (Edisi. Revisi). Jakarta: Rineka Cipta.

---2013. Prosedur penelitian: Suatu Pendekatan Praktik. Jakarta: PT Rineka Cipta

Bryson, John M, 2008 (Penerjemah: Miftahuddin, Perencanaan Strategis bagi Organisasi Sosial: Pengantar: DR. Mansour Fakih, Pustaka Pelajar, yogyakarta.

Cohen, Allan R., Stepen I. Fink, Herman Gadon \& Robin D. Willit. 1980. Effective Behavior In Organizations. Illinois: richard D. Irwin, Inc.

Creswell, John W. 2002. Research Design: Qualitative and Quantitative Approaches. Thousand Oaks. CA Sage.

Decenzo, David A, and Stephen P. Robbins. 1999. Human Development, Sixth Edition, USA, John Willey \& Sons Inc.

Effendy, Khasan, 2010, Memadukan Metode Kuantitatif dan Kualitatif, CV. Indra Prahasta, Bandung.

Hasibuan Malayu, S.P. 2008. Manajemen Sumber Daya Manusia. Jakarta: Bumi Aksara.

Heene, Aime dan Sebastian Desmidt, 2010, Manajemen Strategis Keorganisasian Publik (Penyadur: Faisal Afiff dan Ismeth Abdullah), PT Refika Aditama, Bandung.

Hillway, Moh. Nazir, P. (2014). Metode Penelitian. Bogor: Ghalia Indonesia. 
Kadarisman.2013, .Evaluasi Kinerja SDM. Bandung: Refika Aditama.

Koswara, Kertapraja. E. 2015. Pemerintahan Daerah, Konfigurasi Politik Desentralisasi dan Otomi Daerah untuk Dulu, Kini dan Tantangan Globalisasi. Cetakan Ke 3, Yayasan Damandiri, Inner Bekerja sama dengan Universitas Satyagama, Jakarta.

Labolo, Muhadam, 2013, Memahami Ilmu Pemerintahan: Suatu Kajian, Teori, Konsep dan Pengembangnya, PT Raja Grafindo Persada, Jakarta.

Marczyk, Geoffrey, DeMatteo, David, and Festinger, David. 2005. Essentials of Research Design and Methodology, John Wiley \& Sons, Inc. Hoboken, New Jersey

Mangkunegara, Anwar Prabu, 2008, Manajemen Sumber Daya Manusia Perusahaan, Remaja Rosdakarya, Bandung.

Moh. Nazir, P. (2014). Metode Penelitian. Bogor: Ghalia Indonesia

Moleong, L. J. (2014). Metode Penelitian Kualitatif. Bandung: PT Remaja Rosdakarya Offset.

Rasyid, M. Ryaas. 2007. Kajian Awal Birokrasi Pemerintahan dan Politik Orde Baru, : Yarsif Watampone, Jakarta.

Rangkuti, Freddy, 2014, Analisis SWOT: Teknik Membedah Kasus Bisnis, PT Gramedia Pustaka Utama, Jakarta.

Sedarmayanti, 2014, Manajemen Sumber Daya Manusia: Reformasi Birokrasi dan Manajemen Pegawai Negeri Sipil, PT Refika Aditama, Bandung.

-.2004,GoodGovernance (Kepemerintahan yang Baik) Dalam Rangka Otonomi Daerah, Upaya Membangun Organisasi Efektif dan Efisien Melalui Restrukturisasi dan Pemberdayaan, CV.Mandar Maju, Bandung.

Siagian, Sondang P. 2008. Organisasi Kepemimpinan \& Perilaku Administrasi, Toko Gunung Agung; Jakarta.

---------. 2009, Manajemen Sumber Daya Manusia, Bumi Aksara. Jakarta.

Silalahi, U. (2012). Metode Penelitian Sosial. Bandung: Refika Aditama.
Sumaryadi, I Nyoman, 2010, Sosiologi Pemerintahan: Dari Perspektif Pelayanan, Pemberdayaan, Interaksi dan Sistem Kepemimpinan Pemerintahan Indonesia, Penerbit Ghalia Indonesia, Bogor.

Susan Stainback Sugiyono. (2015: 244). Metode Penelitian Kuantitatif Kualitatif dan R\&D. Bandung: Pustaka Pelajar.

Sugiyono. 2014. Metode Penelitian Kombinasi (Mixed Methods). Bandung: Alfabeta.

2013. Metode Penelitian Pendidikan (Pendekatan Kuantitatif, Kualitatif, dan R\&D. Bandung: Alfabeta.

2011, Metode Penelitian Kuantitatif, Kualitatif dan R\&D, Alfabeta, Bandung.

Suradinata, Ermaya. 2008, Membangun Daerah Menuju Indonesia Bangkit. Elex Media Komputindo. Jakarta.

Suriasumantri, Jujun S. 1998, Filsafat Ilmu Sebuah Pengantar Populer, Pustaka Sinar Harapan, Jakarta.

Thoha, Miftah, 2008. Deregulasi dan Debirokratisasi dalam Upaya Peningkatan Mutu Pelayanan Masyarakat, Pembangunan Administrasi di Indonesia.: LP3ES, Jakarta.

Utomo, 2000 Metode Penelitian Kualitatif, Kuantitatif Analisis SWOT, Refika Aditama, Bandung

Wasistiono. 2014. Metode Penelitian. Bogor: Ghalia Indonesia

Wechsler dan Backoff dalam Henee dan Desmidt (2010: 62), Manajemen Strategis Keorganisasian Publik (Penyadur: Faisal Afiff dan Ismeth Abdullah), PT Refika Aditama, Bandung.

Widayana. 2005. Knowledge Management Meningkatkan daya Daya Saing.: Bayumedia Publishing, Surabaya.

\section{Peraturan Perundang-Undangan}

Undang-Undang No. 23 Tahun 2014 tentang Pemerintahan Daerah 
Perpres No. 81 Tahun 2010 tentang Grand Design Reformasi Birokrasi.

Keputusan Menteri Pendayagunaan Aparatur Negara Nomor: KEP/25/M.PAN/2/2004, 24 Februari 2004 tentang Pedoman Umum Penyusunan Indeks Kepuasan Masyarakat Unit Pelayanan Instansi Pemerintah

Peraturan Daerah Kabupaten Sumedang No. 9 Tahun 2014 tentang Pembentukan Organisasi Perangkat Daerah Kabupaten Sumedang

Peraturan Pemerintah No. 101 Tahun 2000 tentang Pendidikan dan Pelatihan Jabatan Pegawai Negeri Sipil

\section{Dokumen}

Rencana Pembangunan Jangka Menengah Daerah Kabupaten Sumedang 2013-2018

Rencana Strategis Badan Kepegawaian dan Pengembangan Sumber Daya Manusia Kabupaten Sumedang 2014-2018

Rencana Tata Ruang Wilayah Kabupaten Sumedang Tahun 2011-2031

Laporan Penyelenggaraan Pemerintah Daerah Kabupaten Sumedang Tahun 2017 dan Profil BKPSDM Kabupaten Sumedang Tahun 2017, LAKIP BKPSDM Kabupaten Sumedang. 